\title{
1 ASSESSING METAL POLLUTION IN PONDS CONSTRUCTED FOR 2 CONTROLLING RUNOFF FROM RECLAIMED COAL MINES
}

3 Leticia Miguel-Chinchilla ${ }^{1 *}$

4 Eduardo González ${ }^{2,3,4}$

5 Francisco A. Comín ${ }^{1}$

6

$7 \quad{ }^{1}$ Pyrenean Institute of Ecology, Spanish National Research Council. Zaragoza, 50059 Spain

$8 \quad{ }^{2}$ Université de Toulouse; INP, UPS; EcoLab; 31062 Toulouse, France

$9 \quad{ }^{3}$ CNRS; EcoLab; 31062 Toulouse, France

$10{ }^{4}$ Department of Biological Sciences, University of Denver. Denver, CO 80209 USA

* Corresponding author: leticia.m.ch@gmail.com

ABSTRACT

16 Constructing ponds to protect downstream ecosystems is a common practice in opencast coal mine 17 reclamation. As these ponds remain integrated in the landscape, it is important to evaluate the extent 18 of the effect of mine pollution on these ecosystems. However, this point has not been sufficiently 19 addressed in the literature. The main objective of this work was to explore the metal pollution in 20 manmade ponds constructed for runoff-control in reclaimed opencast coal mines over time. To do 21 so, we evaluated the concentration of 10 heavy metals in the water, sediment and Typha sp. in 16 runoff ponds ranging from 1 to 19 years old that were constructed in reclaimed opencast coal mines of northeastern Spain. To evaluate degree of mining pollution, we compared these data to those from a pit-lake created in a local un-reclaimed mine and to local streams as an unpolluted reference, as well as comparing toxicity levels in aquatic organisms. The runoff ponds showed toxic concentrations of $\mathrm{Al}, \mathrm{Cu}$ and $\mathrm{Ni}$ in the water and $\mathrm{As}$ and $\mathrm{Ni}$ in the sediment, which were maintained over time. Metal concentrations in runoff ponds were higher than in local streams, and macrophytes showed high metal concentrations. Nevertheless, metal concentrations in water and sediment in runoff ponds were lower than those in the pit-lake. This study highlights the importance of mining reclamation to preserve the health of aquatic ecosystems and suggests the existence of chronic metal toxicity in the ponds, potentially jeopardizing pond ecological functions and services.

Key words: runoff control; manmade ponds: heavy metals; reclamation; restoration; coal mining; 
36 Surface coal mining operations remove the soil and rocks over the coal seam (overburden) to gain access to the underlying coal. Despite reclamations, surface mining produces major environmental disturbances due to excavation operations, including deforestation, topsoil loss, topological alterations, soil compaction, hydrological changes and aquatic contamination (Shrestha and Lal 2006; Cravotta 2008; Pond et al. 2008; Palmer et al. 2010). Among all disturbances, the heavy metal pollution derived from acidic mine drainage (hereafter called AMD) is one of the greatest threats to the aquatic ecosystems because heavy metals degrade the aquatic habitat and are potentially toxic to aquatic organisms (Dunbabin and Bowmer 1992; MacDonald et al. 2000; Cravotta 2008).

The main goal of mine reclamation is to isolate the pollutants from the ecosystems located downstream of the mine sites. This objective should be achieved in combination with the final use of the reclaimed mine (e.g., production of biomass for energy and sustain natural grassland and forest) because the resulting ecosystem will remain integrated in the landscape (Bungart and Hüttl 2001; Nicolau 2003; Gould 2012; Vickers et al. 2012). The control of the offsite effects are addressed by the design of stable relief forms and safety structures, such as wetlands and ponds that guarantee the non-emission of sediments and contaminants from restored sites to adjacent natural watercourses (Sawtsky et al. 2000; Nicolau 2003; Wong 2003). These water bodies are normally constructed with two objectives: the control of the runoff generated in the reclaimed mines and the specific treatment of AMD.

The water bodies constructed to retain the runoff may be affected by metal pollution although water has neutral $\mathrm{pH}$ and sediment does not show red, orange or yellow iron precipitates. In reclaimed mines, coal mineral could be present in the overburden materials used to reconstruct the topography, and metals could be released from the oxidation of pyrite present in the coal mineral (Johnson 2003; Sheoran and Sheoran 2006; Cravotta 2008; Griffith et al. 2012). The manmade wetlands and ponds remain integrated in the landscape after the end of mining reclamation and may provide new ecological functions and services to society, such as aquatic fauna habitats and recreational areas. But these functions ultimately depend on the quality of the ecosystem. Therefore, to know the extent to which wetlands and ponds are affected by metal pollution is an important issue that nevertheless was insufficiently addressed in the extant literature. for runoff-control in reclaimed coal mines (hereafter called runoff ponds). Specifically, we were interested in evaluating the temporal changes in metal concentrations to determine if toxic concentrations of metals were present in the aquatic ecosystem. The temporal study of the metal pollution for runoff ponds was done using a chronosequence approach. A comprehensive assessment 
which are three main factors involved in the process of heavy metal removal (Dunbabin and Bowmer 1992; Sheoran and Sheoran 2006).

MATERIAL AND METHODS

\section{Site description}

The study was conducted in the Teruel coalfield, a mountainous area that is located in central-eastern Spain (Fig. 1) and characterized by a continental Mediterranean climate. In this area, coal extraction requires the construction of an external dump. As mining advances through the coalfield along the coal seam, the overburden is used to refill the previously mined pits, and the post-mining topography is created according to different reclamation objectives. We selected 16 manmade ponds created during mine reclamation to control the runoff from reclaimed mines (Fig. 1B). Pond age ranged from 1 to 19 years old, so we used a space-for-time approach to evaluate metal pollution over time. Due to logistic constraints in the samplings, chronosequences are frequently used instead of long data series (Majer and Nichols 1998; Walker et al. 2010; Hart and Davis 2011). The runoff ponds were designed mimicking natural ecosystems so that they would not require permanent human management. The runoff ponds were oval shaped, and the area ranged from 0.2 to 3.9 ha with an exception of one of them, which had an area of 22 ha. Littoral vegetation was dominated by Typha sp. distributed in an average band of $1.5 \mathrm{~m}$ around the pond. All ponds were permanent and endorheic; except for two ponds that were connected to a small stream, the water arrived from superficial and sub-superficial runoff during rain events.

93

In addition to the 16 runoff ponds, we sampled one pit-lake from an un-reclaimed coal mine within the same study area. Pit-lakes, which are formed when water fills excavated mining pits, are typically deep lakes with vertical walls. The pit-lake surface was 7.6 ha, and the pit-lake was narrow, deep, without a littoral zone and vegetation and enclosed by steep rock walls averaging $10 \mathrm{~m}$ high. The low water level and steep banks, typical characteristics of the un-reclaimed pit-lakes in the study area, make sampling extremely difficult and dangerous, and these conditions prevented us from including other pit-lake replicates in the study. The sampled pit-lake was older than 25 years old.

Finally, unpublished data of metal content in local streams were also considered to compare with

103 data collected in the runoff ponds and used as a reference. Stream water and sediment samples were 104 collected from 26 points along the mainstream (Martín River) and their principal tributaries in spring 105 and summer of 2008 (Fig. 1A). Only dissolved metals in water and total metals in sediment are available. 
110 In the spring and summer of 2009, the water conductivity $\left(\mu \mathrm{S} \mathrm{cm}^{-1}\right)$ and $\mathrm{pH}$ were measured in situ at

111 each pond using calibrated portable probes (WTW Multiline P4, Weilheim, Germany). All the

112 material used for metal analysis was soaked in $10 \% \mathrm{HNO}_{3}$ (Sastre et al. 2002). The water was

113 collected using polyethylene bottles at a depth of 15-20 cm. Samples were placed in portable

114 refrigerators and immediately transported to the lab for further analyses. In the lab samples were

115 stored in a refrigerator until the analysis were done. The alkalinity ( $\mathrm{mg} \mathrm{l}^{-1}$ ) was determined by $\mathrm{pH}$

116 potentiometric automatic titration with $0.004 \mathrm{~N} \mathrm{H}_{2} \mathrm{SO}_{4}$ (Metrohm, Herisau, Switzerland) within the

$11724 \mathrm{~h}$ after collection. The water samples were filtered through pre-ashed and deionizer water cleaned

$1180.45 \mu \mathrm{m}$ cellulose acetate filters. The dissolved $\mathrm{SO}_{4}{ }^{2-}\left(\mathrm{mg} \mathrm{l}^{-1}\right)$ was determined by ion chromatography

119 (Metrohm 861 Advanced Compact IC, Herisau, Switzerland). In addition, we determined ten

120 dissolved trace metals ( $\mathrm{mg}^{-1}$ ), $\mathrm{Al}, \mathrm{As}, \mathrm{Cd}, \mathrm{Cr}, \mathrm{Cu}, \mathrm{Fe}, \mathrm{Mn}, \mathrm{Ni}, \mathrm{Pb}$ and $\mathrm{Zn}$, using Inductively

121 Coupled Plasma Optical Emission Spectrometry (ICP-OES iCAP6300Duo; Thermo Fisher,

122 Waltham, MA, USA). After filtering, water aliquots for metal analysis were immediately acidified to

$123 \mathrm{pH}<2$ with ultrapure $\mathrm{HNO}_{3}$ and kept at $4^{\circ} \mathrm{C}$ until analysis. The analyses performed in the lab

124 followed standard American Public Health Association methods (APHA et al. 1992). Solution

125 standards were appropriately diluted and used to calibrate the ICP-OES before metal determinations.

126 Quality control for metal analysis was attained by including blanks and sample duplicates. The limits

127 of detection in to water samples were $\mathrm{Al}=0.04 \mathrm{mg} \mathrm{l}^{-1}, \mathrm{As}=0.08 \mathrm{mg} \mathrm{l}^{-1}, \mathrm{Cd}=0.01 \mathrm{mg} \mathrm{l}^{-1}, \mathrm{Cr}=0.01$

$128 \mathrm{mg} \mathrm{l}^{-1}, \mathrm{Cu}=0.01 \mathrm{mg} \mathrm{l}^{-1}, \mathrm{Fe}=0.02 \mathrm{mg} \mathrm{l}^{-1}, \mathrm{Mn}=0.002 \mathrm{mg} \mathrm{l}^{-1}, \mathrm{Ni}=0.03 \mathrm{mg} \mathrm{l}^{-1}, \mathrm{~Pb}=0.07 \mathrm{mg} \mathrm{l}^{-1}$ and $\mathrm{Zn}=$ $1290.005 \mathrm{mg} \mathrm{l}^{-1}$.

130

\section{Sediment}

132 One composite sample of sediment was collected from three points in the littoral zone of each pond, 133 where Typha sp. grows, in the spring and summer of 2009. Sediment samples were taken using a

134 hand corer sediment sampler $50 \mathrm{~mm}$ dia. The sampling was limited to the superficial sediment (i.e.,

135 top $\sim 10 \mathrm{~cm}$ ) because most physical and chemical changes in sediments occur within the upper $10 \mathrm{~cm}$

136 layer (Meyer et al. 2008). The sediment $\mathrm{pH}$ and conductivity $\left(\mu \mathrm{S} \mathrm{cm}^{-1}\right)$ were measured in the lab in a

137 solution of $10 \mathrm{~g}$ of fresh sediment dispersed in deionized water $\left(\mathrm{pH}: 2.5: 1 \mathrm{~g} \mathrm{ml}^{-1}\right.$, conductivity: 5:1 $\mathrm{g}$

$138 \mathrm{ml}^{-1}$ ) after shaking for $30 \mathrm{~min}$. The collected sediments were air dried and sieved into fractions. The

$139<2 \mathrm{~mm}$ fraction was used to determine the total sulfur (\%) using an elemental analyzer (LECO SC-

140 144DR; Leco Instruments, St. Joseph, MI, USA). The $<63 \mu \mathrm{m}$ fraction was used to determine the 141 total and extractable metals ( $\mathrm{mg} \mathrm{kg}^{-1} \mathrm{DW}$ ): $\mathrm{Al}, \mathrm{As}, \mathrm{Cd}, \mathrm{Cr}, \mathrm{Cu}, \mathrm{Fe}, \mathrm{Mn}, \mathrm{Ni}, \mathrm{Pb}$ and $\mathrm{Zn}$ (Förstner and

142 Wittmann 1983; Casas et al. 2003). Total metal concentration was analyzed per the US

143 Environmental Protection Agency 3051A Method (US EPA 2007), and the extractable metals were

144 obtained using acetic acid (Davidson et al. 1994; Rauret 1998; Pueyo et al. 2001). In both cases,

145 sediment digestion was performed by microwave extraction (Speedwave MWS-3, Berghof,

146 Germany). Total and the extractable metals were determined using the ICP-OES following 
147 American Public Health Association methods (APHA et al. 1992), in the same way as in water

148 samples. The limits of detection to sediment were $0.01 \mathrm{mg}^{-1}$ for the 10 studied metals.

150 Vegetation (Typha sp.)

151 In the summer of 2009, we collected three plants of Typha sp. at the perimeter of each runoff pond.

152 The plants were carefully washed using tap and distilled water, cleaned by immersion in $0.01 \mathrm{M}$ 153 ethylenediaminetetraacetic acid (EDTA) to remove any absorbed metals and finally rinsed with 154 deionized water (Carranza-Alvarez, Alonso-Castro et al. 2008). Later, the plants were dried to 155 constant weight at $60^{\circ} \mathrm{C}$. The metal concentration in the tissues of Typha sp. varied, with root $>$ 156 rhizome > leaf (Dunbabin and Bowmer 1992; Sasmaz et al. 2008), so the dried plants were separated 157 into leaf, root and rhizome and grounded in a laboratory mixer mill (MM400 Retsch, Haan, 158 Germany) using teflon recovered grinding jards and balls. The plant material was digested with 159 nitric acid to solubilize metals (Meeravali and Kumar 2000; Sastre et al. 2002) using a microwave 160 system to reduce the total analysis time and the risk of sample contamination (Nadkarni 1984; Smith 161 and Arsenault 1996; Sastre et al. 2002). Finally, Al, As, Cd, Cr, Cu, Fe, Mn, Ni, Pb and Zn were 162 determined in ICP-OES following APHA et al. (1992) methods as describe above for the water 163 samples. The limits of detection to plant tissues were $0.01 \mathrm{mg}^{-1}$ for the ten studied metals. The 164 metal concentration in the plant tissues was expressed in $\mathrm{m} \mathrm{kg}^{-1} \mathrm{DW}$.

\section{Data analyses}

\section{Water and sediment}

168 Changes in the water and sediment characteristics in the runoff ponds were assessed over time by 169 linear mixed-effect models (LMM). The LMM allowed for the detection of trends in the change of 170 the environmental variables and control for the effect of the sampling season. For each variable, we 171 built a model in which the fixed factor was the age of the ponds, and sampling season was used as 172 random variable. LMM analyses were conducted with R software v.2.15.1 (R Core Team 2012). We 173 used the function "lme" of the "nlme" package (Pinheiro et al. 2012). The "lme" function assumes 174 that both the random effects and the errors follow normal distributions. All the water and sediment 175 variables, except $\mathrm{pH}$, were transformed with the $\log (\mathrm{x}+1)$ to improve model fitting.

177 The metal toxicity in the runoff ponds was evaluated using several criteria obtained from the 178 literature. To evaluate water pollution, we used the criteria established by the Environmental 179 Protection Agency of United States for the indefinite (CCC: Criterion Continuous Concentration) 180 and brief (CMC: Criteria Maximum Concentration) exposure of aquatic organisms without 181 producing unacceptable effects (US EPA 2002). In addition, we used the toxic concentration of 182 dissolved metals to plants defined by Markert (1992). The sediment metal pollution was evaluated 183 using the quality guidelines for freshwater ecosystems proposed by MacDonald et al. (2000) that 184 provide an accurate basis to predict the absence of sediment toxicity (TEC: Threshold Effect 
185 Concentration) and the presence of sediment toxicity (PEC: Probable Effect Concentration).

186 Moreover, Kruskal-Wallis analyses between metal concentration of runoff ponds and streams were 187 conducted with R software v.2.15.1 (R Core Team 2012), to evaluate the mining effect over aquatic 188 ecosystems located in reclaimed areas. We used the function "kruskal.test" of the "stats" package 189 (Hollander and Wolfe 1973). In addition, the metal concentrations in the runoff ponds were 190 compared to the metal concentration in the pit-lake created within the un-reclaimed coal mine. Aquatic macrophytes

193 We assessed the influence of mining on the macrophytes by comparing the metal concentration of 194 the Typha sp. to the average concentration of metals in plants growing in natural ecosystems 195 following Markert (1992). We did not use a chronosequence approach to analyze metal content in 196 Typha sp. because the time that each plant was exposed to the metals in the runoff pond could not be 197 determined.

\section{RESULTS}

\section{Metal pollution evaluation}

In runoff ponds, heavy metals were rarely detected in water. $\mathrm{As}, \mathrm{Cd}, \mathrm{Fe}$ and $\mathrm{Pb}$ were below the limits

202 of detection and $\mathrm{Cr}$ was only detected in the pit-lake, therefore were not shown in the figures. Water

$203 \mathrm{Al}, \mathrm{Cu}, \mathrm{Mn}, \mathrm{Ni}$ and $\mathrm{Zn}$ concentrations were above detection limits and shown in Figure 2. The water 204 in the runoff ponds had a neutral $\mathrm{pH}(7.67 \pm 0.16)$. The water $\mathrm{pH}$ in the pit-lake was acidic $(3.48 \pm$ 205 0.06) and alkalinity was not detected. The concentrations of sulfate, $\mathrm{Al}, \mathrm{Cu}, \mathrm{Mn}, \mathrm{Ni}$ and $\mathrm{Zn}$ in the pit 206 lake were several orders of magnitude higher than the runoff ponds (Fig. 2 from (a) to (i)). 207 According to the criteria proposed by the US EPA (2002), the dissolved $\mathrm{Al}, \mathrm{Cu}$ and $\mathrm{Ni}$ 208 concentrations in the runoff ponds were above $\mathrm{CCC}$ criteria and only the $\mathrm{Cu}$ concentration were 209 above CMC criteria. Ni was in the same order of magnitude than CCC, Al was four times greater 210 than the $\mathrm{CCC}$ criteria, and mean $\mathrm{Cu}$ was six times greater than $\mathrm{CCC}$ and four times greater than 211 CMC. The pit-lake showed $\mathrm{Al}, \mathrm{Cr}, \mathrm{Cu}, \mathrm{Ni}$, and $\mathrm{Zn}$ metal concentrations above $\mathrm{CCC}$ criteria and $\mathrm{Al}$, $212 \mathrm{Cr}, \mathrm{Cu}$ and $\mathrm{Zn}$ concentrations above $\mathrm{CMC}$ criteria. In fact, the differences between the pit-lake and 213 reference levels were much higher than between the runoff ponds and the reference levels (Fig. 2 214 from (e) to (i)); notably, the $\mathrm{Al}$ and $\mathrm{Cu}$ metal concentrations in the pit-lake were more than 100 times 215 greater. Among all metals in runoff ponds and the pit-lake, only Al in the pit-lake (Fig. 2(e)) 216 exceeded the toxicity values established for plants in Markert (1992).

218 Total metal concentrations in sediment were detected in a high percentage of samples (from 60 to $219100 \%$ ) for most of the studied metals, with the exception of $\mathrm{Cd}$, which was below its limit of detection. Extractable concentrations of metals in sediments were detected in less than $50 \%$ of samples and $\mathrm{As}, \mathrm{Cd}, \mathrm{Cr}$ and $\mathrm{Pb}$ were below limit of detection (data not shown in figures). 
222 Concentration of $\mathrm{Al}, \mathrm{As}, \mathrm{Cr}, \mathrm{Cu}, \mathrm{Fe}, \mathrm{Mn}, \mathrm{Ni}, \mathrm{Pb}$ and $\mathrm{Zn}$, to both, total and extractable fractions, were

223 shown in Figure 3. In the sediment, the $\mathrm{pH}$ was neutral in the runoff ponds $(7.32 \pm 0.19)$ and acidic

$224(4.73 \pm 1.23)$ in the pit-lake, and the total sulfur was three times higher in the pit-lake than in the

225 runoff ponds (Fig. 3 (a) and (c) respectively). Despite these results, we did not detect differences in

226 the total and extractable heavy metals among runoff ponds and the pit-lake (Fig. 3 from (d) to (1)). In

227 both water bodies, only As and Ni exceeded the quality guidelines established by MacDonald et al.

228 (2000) for sediments in freshwater ecosystems. Notably, mean Ni was 20 times higher than the

229 threshold value of TEC criteria, and approximately 10 times higher than PEC in both the runoff

230 ponds and the pit-lake.

231

232 Metal concentration in streams are shown in Table 1. Al, $\mathrm{Cd}, \mathrm{Cu}, \mathrm{Ni}, \mathrm{Pb}$ and $\mathrm{Zn}$ were below the limit 233 of detection in water samples and $\mathrm{Cd}$ in sediment samples. The comparison of runoff ponds and 234 stream metal concentration showed that dissolved $\mathrm{Al}, \mathrm{Cu}, \mathrm{Ni}$ were present in runoff pond but absent 235 in streams and also that Mn showed a higher concentration in runoff ponds (Kruskal-Wallis test, $\mathrm{P}<$ 236 0.001). Dissolved Fe was present in streams and absent in runoff ponds, but was only detected in $23720 \%$ of the stream samples. Total sediment concentration of $\mathrm{As}, \mathrm{Cu}, \mathrm{Fe}$ and $\mathrm{Zn}$ were higher in runoff 238 ponds than in streams (Kruskal-Wallis test, $\mathrm{P}<0.001, \mathrm{P}=0.014, \mathrm{P}=0.002$ and $\mathrm{P}=0.018$ 239 respectively). Al total concentration in sediment was significantly higher in the streams (Kruskal240 Wallis test, $\mathrm{P}=0.028$ ) although mean concentrations in runoff ponds and in streams were in the 241 same order of magnitude.

242

243 Finally, concentration of metals in plants were found in most of samples in a high percentage, with

244 the exception of $\mathrm{Cd}$ and $\mathrm{Cr}$ that were below limits of detection. Metal concentration in plants (except $245 \mathrm{Cd}$ and $\mathrm{Cr}$ ) were shown in Figure 4. The Typha sp. exceeded the average metal concentration of $\mathrm{Al}$, $246 \mathrm{As}, \mathrm{Fe}$ and $\mathrm{Ni}$ in a great percentage of samples, especially in the roots and rhizomes where was near $247100 \%$ (Fig. 4 a, b, d and f). It is noteworthy that Fe was more than 100 times higher than the mean 248 concentration in plants defined by Markert (1992).

250 Changes over time

251 Runoff ponds had similar values in the heavy metals carried by water, as well as in $\mathrm{pH}$, conductivity 252 alkalinity and sulfate concentration, regardless of age (LMM analysis, $\mathrm{P}>0.05$ ). The conductivity, 253 total sulfur, $\mathrm{As}, \mathrm{Fe}$ and $\mathrm{Zn}$ in the sediment increased with pond age (LMM analysis: $\mathrm{t}=+2.687, \mathrm{P}=$ $2540.012 ; \mathrm{t}=+3.572, \mathrm{P}=0.001 ; \mathrm{t}=+2.662, \mathrm{P}=0.013 ; \mathrm{t}=+4.284, \mathrm{P}<0.001 ;$ and $\mathrm{t}=+2.169, \mathrm{P}=0.038$ 255 respectively). Despite the increase over time, toxic levels of As in the sediment to the aquatic organisms were maintained above TEC and below PEC thresholds. 
260 The references used to detect metal toxicity in the aquatic organisms showed potentially toxic levels 261 of $\mathrm{Al}, \mathrm{Cu}$ and $\mathrm{Ni}$ in water and $\mathrm{As}$ and $\mathrm{Ni}$ in sediment (MacDonald et al. 2000; US EPA 2002). In 262 addition, the higher metal concentration in runoff ponds than in local streams evidenced the effect of 263 metal pollution from coal mining. Ponds are generally considered to be good metal sinks (Dunbabin 264 and Bowmer 1992; Mitsch and Wise 1998; Sheoran and Sheoran 2006; Merricks et al. 2007). 265 However, the case of the Teruel coalfield showed that the pond's ability to retain metals in the 266 sediment did not completely reduce the water's metal concentration below levels toxic to the aquatic 267 organisms. CCC, CMC, PEC and TEC criteria consider the negative effects that heavy metals could 268 cause for a wide range of aquatic organisms (plankton, macroinvertebrates and fishes). Therefore, 269 the persistent metal concentration above toxic levels over time may compromise the composition 270 and development of the entire aquatic community. For example, metal pollution in aquatic sites 271 could reduce the taxonomic richness of macroinvertebrate communities and induce a shift toward 272 more tolerant taxa (Clements 1994; David 2003; Merricks et al. 2007; Loayza-Muro et al. 2010). 273 Indeed, a low macroinvertebrate biodiversity was found in the studied runoff (Miguel-Chinchilla 274 2013; Miguel-Chinchilla et al. 2014). In addition, in fishes, heavy metals may restrict the presence of 275 some species, reduce embryonic survival and increase the frequency of body malformations and 276 deaths (Dubé et al. 2005; Lindberg et al. 2011; Witeska et al. 2013).

277

278 Although metal concentrations in the runoff ponds were not above levels considered to be toxic to 279 plants (Markert 1992), the effects of the high metal concentrations were reflected in the study of the 280 Typha sp. We detected Al, As, Fe, and Ni concentrations in the Typha sp. that were well above 281 concentrations considered to be normal for plants (Markert 1992) and higher than the metal 282 concentration of Typha sp. growing in non-polluted sites (Babcock et al. 1983; Samecka-Cymerman 283 and Kempers 2001). Typha sp. is known to accumulate high amounts of metals in their tissues 284 (McNaughton et al. 1974; Ye et al. 2003; Demirezen and Aksoy 2004), and our results are consistent 285 with these previous findings. This accumulation of metals in the plant tissues could be a long-term 286 problem because when plants die, metals in their tissues return to the ecosystems into detritus and 287 during decomposition become more available, particularly to deposit feeders (Dorgelo et al. 1995; 288 Weis and Weis 2004). Remarkably, Typha sp. was almost the only macrophyte in the runoff ponds. 289 This observation suggests that other plants were less competitive than Typha and unable to establish 290 due to prevalent heavy metal levels in the runoff ponds, indicating that ponds ultimately suffered 291 from undesirable heavy metal pollution.

293 The accumulation of metals in the pond may not necessary indicate that ponds will be their final sink 294 (Dunbabin and Bowmer 1992). Even if ponds have an endorheic character (similar to our study 295 case), possible negative effects over downstream ecosystems should be considered. For example, 296 metal exportation outside the reclaimed mines could happen during high storm events (Mitsch and 
297 Gosselink 2000; Griffith et al. 2012) and through the food web (Braune et al. 1999; Parker 2004;

298 Croteau et al. 2005).

300 Metal pollution persists in runoff ponds over time

301 The temporal approach used in this study indicates that metal pollution in the runoff ponds persisted

302 even 19 years after their construction. Similarly, other studies revealed that heavy metal pollution in

303 streams close to reclaimed coal mines was detected even more than 20 years after mining

304 reclamation finished (Hartman et al. 2005; Clements et al. 2010; Hopkins et al. 2013). The increase

305 of total sulfur, $\mathrm{As}, \mathrm{Fe}$ and $\mathrm{Zn}$ in sediments over time may evidence a continuous introduction of

306 metals into the runoff ponds. When coal mine spoils are exposed to natural weathering conditions,

307 the pyretic minerals contained in the coal are oxidized in presence of oxygen and water, producing

308 sulfuric acid and releasing heavy metals (Johnson 2003; Sheoran and Sheoran 2006; Cravotta 2008).

309 Thus, sulfates and metals could move from the reclaimed mines into the runoff ponds during rain

310 events dissolved in the water runoff. Moreover, soil and overburden erosion during storm events

311 could mobilize sulfur and metals in suspension.

312

313 Despite continuous metal introduction into the runoff ponds, the $\mathrm{pH}$, alkalinity, $\mathrm{SO}_{4}{ }^{2-}$ and dissolved

314 heavy metals in water and the extractable metals in sediment did not change over time. These results

315 suggest that during the studied period, represented by the chronosequence, the runoff ponds had a

316 chemical equilibrium that may be favored by carbonate parent material that provides extensive

317 internal buffering capacity (Pond et al. 2008; Bernhardt and Palmer 2011; Griffith et al. 2012).

318 Nevertheless, the observed chemical equilibrium in the runoff ponds may be altered by sediment $\mathrm{pH}$

319 changes in the future. This can sometimes occur when reduced sediment become oxidized, then stored metals may be released to more mobile forms (Gambrell 1994).

\section{Relevance of mine reclamation}

323 The concentration of heavy metals in the water of the runoff ponds was significantly lower than the concentration of heavy metals found in the pit-lake located in the un-reclaimed mine. Although the pit-lake was formed in a limestone area more than 25 years ago, it had a low $\mathrm{pH}$ and high concentrations of sulfate and heavy metals typical in this type of lakes (Blodau 2006; Yucel and Baba 2012). The concentrations of most of the studied metals in the water of the pit-lake were above the levels considered to be toxic for the aquatic organisms. Moreover, the combination of the acidic $\mathrm{pH}$ and the toxic level of $\mathrm{Al}$ could contribute to the absence of macrophytes and aquatic plants in the

330 pit-lake (Markert 1992; Samecka-Cymerman and Kempers 2001; Brix et al. 2002). Therefore, if opencast coal mines had not been reclaimed in our study area, it is expectable that acidic and metal polluted lakes with poor conditions to sustain a biological community would have formed. In

333 accordance to previous works (Younger 2001; Rodrigue et al. 2002; Wei et al. 2011), our study

334 highlighted the relevance of opencast coal mine reclamation. 


\section{CONCLUSIONS AND MANAGEMENT IMPLICATIONS}

337 Currently, the study of mining pollution is primarily focused on the study of downstream 338 ecosystems, and on constructed wetlands and ponds to specific AMD treatment. Nevertheless, 339 reclaimed mines also support aquatic ecosystems that could be highly affected by mining as shown 340 by our results. Even though reclamation of opencast coal mines plays a key role in reducing metal 341 pollution and obtaining functional ecosystems in post-mining landscapes, mine reclamation does not 342 completely avoid metal pollution, supporting higher concentration in the constructed runoff ponds 343 than in local streams. Metal concentrations were maintained over time, and in some cases even 344 increased, indicating that metal pollution may be a chronic problem. This is a relevant issue that may 345 determine the future land use of the reclaimed mines. Monitoring and control of post-mining areas 346 are therefore necessary on a long-term basis.

348 Runoff ponds are efficient tools to reduce mining pollution of natural ecosystems under the 349 condition that runoff is managed through endorheic basins. Nevertheless, we advocate a more 350 ambitious goal in restoration of opencast coal mines: metal pollution in manmade ponds should be 351 targeted to be reduced to the lowest level possible. The reclamation of opencast coal-mining 352 landscapes should focus on maintaining self-organized ecosystems in combination with the final use 353 of the post-mining area (Hobbs and Norton 1996). Topography, soil, water and vegetation should be 354 collectively considered in mining management projects to design landscapes that reduce the mining 355 pollution not only downstream but also within the reclaimed mines (Nicolau 2003). The selection of 356 the overburden with the best physical and chemical characteristics in the most superficial layers and 357 the design of a topography that minimizes erosion are important points to consider in post-mining 358 area management to reduce the metal pollution in constructed ponds and their associated aquatic and 359 terrestrial ecosystems.

\section{ACKNOWLEDGMENTS}

362 This work was supported by a research and assistance agreement between Endesa Foundation and 363 the Pyrenean Institute of Ecology-CSIC. The regional government of Aragón, Spain supported the 364 PhD studies of the first author. We are grateful to our fieldwork assistants as well as the Endesa S.A. 365 and their employees in the Teruel mines. Finally we would like to thank to the anonymous reviewer 366 for their helpful comments on a previous version of this manuscript. 
APHA, AWWA, WPCF (1992) Métodos normalizados para el análisis de aguas potables y residuales. Ediciones Díaz de Santos

Babcock MF, Evans DW, Alberts JJ (1983) Comparative uptake and translocation of trace elements from coal ash by typha latifolia. Sci Total Environ 28:203-214. doi: 16/S00489697(83)80019-9

Bernhardt ES, Palmer MA (2011) The environmental costs of mountaintop mining valley fill operations for aquatic ecosystems of the Central Appalachians. Ann N Y Acad Sci 1223:3957. doi: 10.1111/j.1749-6632.2011.05986.x

Blodau C (2006) A review of acidity generation and consumption in acidic coal mine lakes and their watersheds. Sci Total Environ 369:307-332. doi: 10.1016/j.scitotenv.2006.05.004

Braune B, Muir D, DeMarch B, et al. (1999) Spatial and temporal trends of contaminants in Canadian Arctic freshwater and terrestrial ecosystems: a review. Sci Total Environ 230:145207. doi: 10.1016/S0048-9697(99)00038-8

Brix H, Dyhr-Jensen K, Lorenzen B (2002) Root-zone acidity and nitrogen source affects Typha latifolia L. growth and uptake kinetics of ammonium and nitrate. J Exp Bot 53:2441 -2450. doi: $10.1093 / \mathrm{jxb} / \mathrm{erf106}$

Bungart R, Hüttl R. (2001) Production of biomass for energy in post-mining landscapes and nutrient dynamics. Biomass Bioenergy 20:181-187. doi: 10.1016/S0961-9534(00)00078-7

Casas JM, Rosas H, Sole M, Lao C (2003) Heavy metals and metalloids in sediments from the Llobregat basin, Spain. Environ Geol 44:325-332.

Clements WH (1994) Benthic Invertebrate Community Responses to Heavy Metals in the Upper Arkansas River Basin, Colorado. J North Am Benthol Soc 13:30-44. doi: 10.2307/1467263

Clements WH, Vieira NKM, Church SE (2010) Quantifying restoration success and recovery in a metal-polluted stream: a 17-year assessment of physicochemical and biological responses. J Appl Ecol 47:899-910. doi: 10.1111/j.1365-2664.2010.01838.x

Cravotta C (2008) Dissolved metals and associated constituents in abandoned coal-mine discharges, Pennsylvania, USA. Part 1: Constituent quantities and correlations. Appl Geochem 23:166202. doi: 10.1016/j.apgeochem.2007.10.011

Croteau MN, Luoma SN, Stewart AR (2005) Trophic Transfer of Metals along Freshwater Food Webs: Evidence of Cadmium Biomagnification in Nature. Limnol Oceanogr 50:1511-1519. doi: $10.2307 / 3597695$

David CPC (2003) Establishing the impact of acid mine drainage through metal bioaccumulation and taxa richness of benthic insects in a tropical Asian stream (the Philippines). Environ Toxicol Chem 22:2952-2959. doi: 10.1897/02-529

Davidson CM, Thomas RP, McVey SE, et al. (1994) Evaluation of a sequential extraction procedure for the speciation of heavy-metals in sediments. Anal Chim Acta 291:277-286. 
Demirezen D, Aksoy A (2004) Accumulation of heavy metals in Typha angustifolia (L.) and

407

408

409

410

411

412

413

414

415

416

417

418

419

420

421

422

423

424

425

426

427

428

429

430

431

432

433

434

435

436

437

438

439

440

441

442

443

Potamogeton pectinatus (L.) living in Sultan Marsh (Kayseri, Turkey). Chemosphere 56:685696. doi: 10.1016/j.chemosphere.2004.04.011

Dorgelo J, Meester H, Velzen C van (1995) Effects of diet and heavy metals on growth rate and fertility in the deposit-feeding snail Potamopyrgus jenkinsi (Smith) (Gastropoda: Hydrobiidae). Hydrobiologia 316:199-210. doi: 10.1007/BF00017437

Dubé MG, MacLatchy DL, Kieffer JD, et al. (2005) Effects of metal mining effluent on Atlantic salmon (Salmo salar) and slimy sculpin (Cottus cognatus): using artificial streams to assess existing effects and predict future consequences. Sci Total Environ 343:135-154. doi: 10.1016/j.scitotenv.2004.09.037

Dunbabin JS, Bowmer KH (1992) Potential use of constructed wetlands for treatment of industrial wastewaters containing metals. Sci Total Environ 111:151-168. doi: 10.1016/00489697(92)90353-T

Förstner U, Wittmann GTW (1983) Metal pollution in the aquatic environment. Springer

Gambrell R (1994) Trace and toxic metals in wetlands - A reviewT. J Environ Qual 23:883-891.

Gould SF (2012) Comparison of Post-mining Rehabilitation with Reference Ecosystems in Monsoonal Eucalypt Woodlands, Northern Australia. Restor Ecol 20:250-259. doi: 10.1111/j.1526-100X.2010.00757.x

Griffith MB, Norton SB, Alexander LC, et al. (2012) The effects of mountaintop mines and valley fills on the physicochemical quality of stream ecosystems in the central Appalachians: A review. Sci Total Environ 417-418:1-12. doi: 10.1016/j.scitotenv.2011.12.042

Hart TM, Davis SE (2011) Wetland development in a previously mined landscape of East Texas, USA. Wetl Ecol Manag 19:317-329. doi: 10.1007/s11273-011-9218-2

Hartman KJ, Kaller MD, Howell JW, Sweka JA (2005) How much do valley fills influence headwater streams? Hydrobiologia 532:91-102. doi: 10.1007/s10750-004-9019-1

Hobbs RJ, Norton DA (1996) Towards a Conceptual Framework for Restoration Ecology. Restor Ecol 4:93-110. doi: 10.1111/j.1526-100X.1996.tb00112.x

Hollander M, Wolfe DA (1973) Nonparametric statistical methods. John Wiley \& Sons, New York

Hopkins RL, Altier BM, Haselman D, et al. (2013) Exploring the legacy effects of surface coal mining on stream chemistry. Hydrobiologia 713:87-95. doi: 10.1007/s10750-013-1494-9

Johnson DB (2003) Chemical and microbiological characteristics of mineral spoils and drainage waters at abandoned coal and metal mines. Water Air Soil Pollut Focus 3:47-66.

Lindberg TT, Bernhardt ES, Bier R, et al. (2011) Cumulative impacts of mountaintop mining on an Appalachian watershed. Proc Natl Acad Sci 108:20929-20934. doi: 10.1073/pnas.1112381108

Loayza-Muro RA, Elías-Letts R, Marticorena-Ruíz JK, et al. (2010) Metal-induced shifts in benthic macroinvertebrate community composition in Andean high altitude streams. Environ Toxicol Chem 29:2761-2768. doi: 10.1002/etc.327 
MacDonald DD, Ingersoll CG, Berger TA (2000) Development and evaluation of consensus-based sediment quality guidelines for freshwater ecosystems. Arch Environ Contam Toxicol 39:2031.

Majer, Nichols (1998) Long-term recolonization patterns of ants in Western Australian rehabilitated bauxite mines with reference to their use as indicators of restoration success. J Appl Ecol 35:161-182. doi: 10.1046/j.1365-2664.1998.00286.x

Markert B (1992) Presence and significance of naturally-occurring chemical-elements of the periodic system in the plant organism and consequences for future investigations on inorganic environmental chemistry in ecosystems. Vegetatio 103:1-30.

McNaughton SJ, Folsom TC, Lee T, et al. (1974) Heavy Metal Tolerance in Typha Latifolia without the Evolution of Tolerant Races. Ecology 55:1163-1165.

Meeravali NN, Kumar SJ (2000) Comparison of open microwave digestion and digestion by conventional heating for the determination of $\mathrm{Cd}, \mathrm{Cr}, \mathrm{Cu}$ and $\mathrm{Pb}$ in algae using transverse heated electrothermal atomic absorption spectrometry. Fresenius J Anal Chem 366:313-315. doi: $10.1007 / \mathrm{s} 002160050061$

Merricks TC, Cherry DS, Zipper CE, et al. (2007) Coal-mine hollow fill and settling pond influences on headwater streams in southern West Virginia, USA. Environ Monit Assess 129:359-378.

Meyer CK, Baer SG, Whiles MR (2008) Ecosystem Recovery Across a Chronosequence of Restored Wetlands in the Platte River Valley. Ecosystems 11:193-208. doi: 10.1007/s10021-007-9115y

Miguel-Chinchilla L (2013) Physicochemical and Macroinvertebrate Community Trends in Manmade Ponds Constructed in Reclaimed Opencast Coal Mines. Universidad de Alcalá

Miguel-Chinchilla L, Boix D, Gascón S, Comín FA (2014) Macroinvertebrate biodiversity patterns during primary succession in manmade ponds in north-eastern Spain. J. Limnol. 73:

Mitsch WJ, Gosselink JG (2000) Wetlands, 3rd ed. Wiley

Mitsch WJ, Wise KM (1998) Water quality, fate of metals, and predictive model validation of a constructed wetland treating acid mine drainage. Water Res 32:1888-1900. doi: 10.1016/S0043-1354(97)00401-6

Nadkarni RA (1984) Applications of microwave oven sample dissolution in analysis. Anal Chem 56:2233-2237. doi: 10.1021/ac00276a056

Nicolau JM (2003) Trends in relief design and construction in opencast mining reclamation. Land Degrad Dev 14:215-226.

Palmer M, Bernhardt E, Schlesinger W, et al. (2010) Mountaintop Mining Consequences. Science 327:148-149. doi: 10.1126/science.1180543

Parker GH (2004) Tissue metal levels in Muskrat (Ondatra zibethica) collected near the Sudbury (Ontario) ore-smelters; prospects for biomonitoring marsh pollution. Environ Pollut 129:2330. doi: 10.1016/j.envpol.2003.10.003 
Pinheiro J, Bates D, DebRoy S, et al. (2012) nlme: Linear and Nonlinear Mixed Effects Models. R Package Version 31-111

Pond GJ, Passmore ME, Borsuk FA, et al. (2008) Downstream effects of mountaintop coal mining: comparing biological conditions using family- and genus-level macroinvertebrate bioassessment tools. J North Am Benthol Soc 27:717-737. doi: 10.1899/08-015.1

486

Pueyo M, Rauret G, Luck D, et al. (2001) Certification of the extractable contents of $\mathrm{Cd}, \mathrm{Cr}, \mathrm{Cu}, \mathrm{Ni}$, $\mathrm{Pb}$ and $\mathrm{Zn}$ in a freshwater sediment following a collaboratively tested and optimised threestep sequential extraction procedure. J Environ Monit 3:243-250. doi: Article

R Core Team (2012) R: A language and environment for statistical computing. R foundation for Statistical Computing. R Foundation for Statistical Computing, Vienna, Austria

Rauret G (1998) Extraction procedures for the determination of heavy metals in contaminated soil and sediment. Talanta 46:449-455.

Rodrigue JA, Burger JA, Oderwald RG (2002) Forest Productivity and Commercial Value of PreLaw Reclaimed Mined Land in the Eastern United States. North J Appl For 19:106-114.

Samecka-Cymerman A, Kempers AJ (2001) Concentrations of heavy metals and plant nutrients in water, sediments and aquatic macrophytes of anthropogenic lakes (former open cut brown coal mines) differing in stage of acidification. Sci Total Environ 281:87-98.

Sasmaz A, Obek E, Hasar H (2008) The accumulation of heavy metals in Typha latifolia L. grown in a stream carrying secondary effluent. Ecol Eng 33:278-284.

Sastre J, Sahuquillo A, Vidal M, Rauret G (2002) Determination of $\mathrm{Cd}, \mathrm{Cu}, \mathrm{Pb}$ and $\mathrm{Zn}$ in environmental samples: microwave-assisted total digestion versus aqua regia and nitric acid extraction. Anal Chim Acta 462:59-72. doi: 10.1016/S0003-2670(02)00307-0

Sawtsky L, McKenna G, Keys MJ, Long D (2000) Towars Minimising the Long-term Liability of

Sheoran AS, Sheoran V (2006) Heavy metal removal mechanism of acid mine drainage in wetlands:

Shrestha RK, Lal R (2006) Ecosystem carbon budgeting and soil carbon sequestration in reclaimed mine soil. Environ Int 32:781-796. doi: 16/j.envint.2006.05.001

Smith FE, Arsenault EA (1996) Microwave-assisted sample preparation in analytical chemistry. Talanta 43:1207-1268. doi: 10.1016/0039-9140(96)01882-6

US EPA (2002) National Recommended Water Quality Criteria: 2002. Office of Water, EPA-822-R02-047. United States Environmental Protection Agency, Washintong, DC, USA. Accessed

515 Vickers H, Gillespie M, Gravina A (2012) Assessing the development of rehabilitated grasslands on post-mined landforms in north west Queensland, Australia. Agric Ecosyst Environ 163:7284. doi: 10.1016/j.agee.2012.05.024 
518 Walker LR, Wardle DA, Bardgett RD, Clarkson BD (2010) The use of chronosequences in studies 519 of ecological succession and soil development. J Ecol 98:725-736. doi: 10.1111/j.13652745.2010.01664.x

521 Wei X, Wei H, Viadero Jr. RC (2011) Post-reclamation water quality trend in a Mid-Appalachian watershed of abandoned mine lands. Sci Total Environ 409:941-948. doi: 10.1016/j.scitotenv.2010.11.030

524 Weis JS, Weis P (2004) Metal uptake, transport and release by wetland plants: implications for phytoremediation and restoration. Environ Int 30:685-700.

526 Witeska M, Sarnowski P, Ługowska K, Kowal E (2013) The effects of cadmium and copper on embryonic and larval development of ide Leuciscus idus L. Fish Physiol Biochem Adv Online Publ. doi: 10.1007/s10695-013-9832-4

529 Wong M. (2003) Ecological restoration of mine degraded soils, with emphasis on metal contaminated soils. Chemosphere 50:775-780. doi: 10.1016/S0045-6535(02)00232-1

531 Ye ZH, Lin ZQ, Whiting SN, et al. (2003) Possible use of constructed wetland to remove selenocyanate, arsenic, and boron from electric utility wastewater. Chemosphere 52:15711579. doi: 10.1016/S0045-6535(03)00497-1

534 Younger PL (2001) Mine water pollution in Scotland: nature, extent and preventative strategies. Sci Total Environ 265:309-326. doi: 10.1016/S0048-9697(00)00673-2

536 Yucel DS, Baba A (2012) Geochemical Characterization of Acid Mine Lakes in Northwest Turkey and Their Effect on the Environment. Arch Environ Contam Toxicol 64:357-376. doi: $10.1007 / \mathrm{s} 00244-012-9843-7$

539

540 
541 Table 1: Mean and standard deviation of metal concentrations of streams located in the river basin where 542 mines are located. Dissolved metals in water (mg l-1) and total metals in sediment (mg kg-1) are shown. $543 \mathrm{ND}=$ no data.

544

545

\begin{tabular}{rrrrr} 
& \multicolumn{2}{c}{ Water $\left(\mathrm{mg} \mathrm{l}^{-1}\right)$} & \multicolumn{2}{c}{ Total Sediment $\left(\mathrm{mg} \mathrm{kg}^{-1}\right)$} \\
\cline { 2 - 5 } $\mathrm{Al}$ & Average & $\mathrm{SD}$ & \multicolumn{1}{c}{ Average } & \multicolumn{1}{c}{$\mathrm{SD}$} \\
$\mathrm{nys}$ & $<0.04$ & - & 21237.85 & 9447.13 \\
$\mathrm{Cd}$ & $\mathrm{ND}$ & - & 10.06 & 4.02 \\
$\mathrm{Cr}$ & $<0.01$ & - & $<2.50$ & - \\
$\mathrm{Cu}$ & $<0.01$ & - & 26.69 & 9.79 \\
$\mathrm{Fe}$ & $<0.01$ & - & 3.52 & 3.32 \\
$\mathrm{Mn}$ & 0.011 & 0.028 & 22764.96 & 5310.63 \\
$\mathrm{Ni}$ & 0.024 & 0.077 & 364.01 & 163.58 \\
$\mathrm{~Pb}$ & $<0.03$ & - & 199.90 & 301.44 \\
$\mathrm{Zn}$ & $<0.07$ & - & 22.31 & 9.08 \\
\hline
\end{tabular}


546 Figure 1: Study site. Section A: location of the study site (inset) and Martín river basin showing sampling 547 points in the local streams. Section B: Mining area showing the 16 runoff ponds constructed in reclaimed 548 opencast coal mines and the pit-lake located in an un-reclaimed opencast coal mine.

550 Figure 2: Scatter plots of the water characteristics in relation to the runoff pond age. Circles represent 551 spring data, and squares represent summer data. The pit-lake (age $=25 \mathrm{yr}$ ) values were shown in the grey 552 area of the graphic. Dashed lines indicate reference criteria to metal pollution CMC: Criteria Maximum 553 Concentration (US EPA 2002) CCC: Criterion Continuous Concentration (US EPA 2002); PTC: average 554 toxic concentration to plants (Markert 1992). When a range of references exists, $\mathrm{H}$ represents the high 555 value and $L$ represents the low value.

557 Figure 3: Scatter plots of the sediment characteristics in relation to runoff pond age. Circles represent 558 spring data, and squares represent summer data. The pit-lake (age $=25 \mathrm{yr}$ ) values were shown in the grey 559 area of the graphic. Dashed lines indicate reference criteria to metal pollution TEC: threshold effect 560 concentration and PEC: probable effect concentration (MacDonald et al. 2000).

561

562 Figure 4: Metal concentration in Typha sp. root, rhizome and leaf tissues. Dashed lines indicate the 563 averaged range of metal concentrations for plants (Markert 1992), with $\mathrm{H}$ indicating the high and $\mathrm{L}$ the low 564 value of the range. $M$ indicates a unique mean value when a range of references does not exist. 